\title{
Neuropathic Pain Is Constitutively Suppressed in Early Life by Anti-Inflammatory Neuroimmune Regulation
}

\author{
Rebecca McKelvey, ${ }^{1}$ Temugin Berta, ${ }^{2}$ Elizabeth $01 d,{ }^{3}$ Ru-Rong Ji, ${ }^{2}$ and Maria Fitzgerald ${ }^{1}$ \\ ${ }^{1}$ Department of Neuroscience, Physiology and Pharmacology, University College London, London WC1E 6BT, United Kingdom, ${ }^{2}$ Departments of \\ Anesthesiology and Neurobiology, Duke University Medical Center, Durham, North Carolina 27710, and 3Wolfson Centre for Age Related Diseases, King's \\ College London, London WC2R 2LS, United Kingdom
}

Peripheral nerve injury can trigger neuropathic pain in adults but not in infants; indeed, for unknown reasons, neuropathic pain is rare before adolescence. We show here that the absence of neuropathic pain response in infant male rats and mice following nerve injury is due to an active, constitutive immune suppression of dorsal horn pain activity. In contrast to adult nerve injury, which triggers a proinflammatory immune response in the spinal dorsal horn, infant nerve injury triggers an anti-inflammatory immune response, characterized by significant increases in IL-4 and IL-10. This immediate anti-inflammatory response can also be evoked by direct C-fiber nerve stimulation in infant, but not adult, mice. Blockade of the anti-inflammatory activity with intrathecal anti-IL10 unmasks neuropathic pain behavior in infant nerve injured mice, showing that pain hypersensitivity in young mice is actively suppressed by a dominant anti-inflammatory neuroimmune response. As infant nerve injured mice reach adolescence (postnatal day 25-30), the dorsal horn immune profile switches from an anti-inflammatory to a proinflammatory response characterized by significant increases in TNF and BDNF, and this is accompanied by a late onset neuropathic pain behavior and increased dorsal horn cell sensitivity to cutaneous mechanical and cold stimuli. These findings show that neuropathic pain following early life nerve injury is not absent but suppressed by neuroimmune activity and that "latent" pain can still emerge at adolescence, when the neuroimmune profile changes. The data may explain why neuropathic pain is rare in young children and also why it can emerge, for no observable reason, in adolescent patients.

Key words: anti-inflammatory; development; dorsal horn; infant; neuropathic; pain

\section{Introduction}

Neuropathic pain is rare in infants, and only very few reports exist before 5-6 years of age (Anand and Birch, 2002; Sethna et al., 2007; Walco et al., 2010; Howard et al., 2014). Thirteen years is the median age of onset for pediatric neuropathic pain syndromes, such as phantom pain, complex regional pain syndrome, and peripheral neuropathy pain (Walco et al., 2010). The reasons for this are not known. Although many of the underlying disease states involving neuropathic pain are less frequent in children, it is also evident that nerve damage is more likely to trigger pain in late childhood and adolescence than at younger ages (Anand and Birch, 2002; Atherton et al., 2008). Furthermore clinical investigation of phantom limb pain in adolescence

\footnotetext{
Received June 6, 2014; revised Nov. 10, 2014; accepted Nov. 11, 2014.

Author contributions: R.M., T.B., R.-R.J., and M.F. designed research; R.M. and T.B. performed research; T.B., E.O., and R.-R.J. contributed unpublished reagents/analytic tools; R.M., T.B., and M.F. analyzed data; R.M. and M.F. wrote the paper.

This work was funded by the Medical Research Council G0901269 (M.F.) and NIH R01 Grant DE17794 (R.-R.J.). RM was supported by a UCL impact studentship and a UCL Bogue Research Fellowship.

The authors declare no competing financial interests.

This article is freely available online through the J Neurosci Author Open Choice option.

Correspondence should be addressed to Maria Fitzgerald, University College London, Gower Street, London WC1E6BT, UK. E-mail: m.fitzgerald@ucl.ac.uk.

DOI:10.1523/JNEUROSCI.2315-14.2015

Copyright $\odot 2015$ McKelvey et al.

This is an Open Access article distributed under the terms of the Creative Commons Attribution License (http://creative commons.org/licenses/by/3.0), which permits unrestricted use, distribution and reproduction in any medium provided that the original work is properly attributed.
}

shows that children with the earliest amputations had a delayed onset of phantom pain, emerging after a mean of 7 years (Melzack et al., 1997).

The absence of neuropathic pain in early life is confirmed in nerve injury infant rat and mice models (Howard et al., 2005; Moss et al., 2007; Costigan et al., 2009; Vega-Avelaira et al., 2012), where no pain behavior is observed if the nerve injury is performed before 3 weeks [postnatal day (P)21] of age. In addition, whereas adult neuropathic pain is accompanied by activation of microglia, T-cell infiltration and the release of proinflammatory immune mediators in the dorsal horn, critical for sensitization and pain-like hypersensitivity (Taves et al., 2013; Tsuda et al., 2013), this proinflammatory immune response is absent when the same surgery is performed before P21 (Moss et al., 2007; Vega-Avelaira et al., 2007; Costigan et al., 2009). Because infant rats and mice are capable of developing clear pain hypersensitivity upon inflammation (Marsh et al., 1999; Walker et al., 2005) and in response to spinal cord glutamate or lipopolysaccharide application (Moss et al., 2007), the absence of neuropathic pain behavior following nerve injury in infant rodents has been ascribed to immature neuroimmune pathways, rather than a failure of pain circuitry per se (Costigan et al., 2009; Vega-Avelaira et al., 2012).

Recent longitudinal studies in rats have revealed a previously unsuspected aspect of the ontogeny of neuropathic pain, namely that animals that undergo nerve injury in early life do eventually develop pain hypersensitivity, but only when they 
reach adolescence, age P25-P30 (Vega-Avelaira et al., 2012). A similar delayed onset was observed, in passing, in neuropathic autotomy in young animals (Wall et al., 1979). These data raise the intriguing possibility that neuropathic pain is not so much absent in infants, as suppressed until the animal reaches adolescence.

Here, we show that nerve injury in early life triggers an antiinflammatory response in the dorsal horn that actively suppresses hypersensitivity. At adolescence, the immune response switches to proinflammatory, coinciding with the onset of behavioral hypersensitivity and increased dorsal horn neuron activity. These results provide a novel mechanistic explanation for the developmental profile of neuropathic pain and suggest that infant neuropathic pain following nerve injury, although not immediately experienced, is latent and may emerge in later life.

\section{Materials and Methods}

Experiments were performed on male Sprague-Dawley rats or male CD1 mice aged $\mathrm{P} 33$ or pups aged P10. All animal procedures were licensed by the UK Home Office (London, United Kingdom) in accordance with the UK Animal (Scientific Procedures) Act 1986 and by the Institutional Animal Care and Use Committee of Duke University.

Animal surgery. Spared nerve injury (SNI) surgery was performed in male rats and mice under general anesthesia with $2-3 \%$ isoflurane in oxygen as described previously (Decosterd and Woolf, 2000; Pertin et al., 2012). The sciatic nerve was exposed in the upper lateral thigh and the common peroneal and tibial branches tightly ligated and transected distally leaving the sural nerve intact. Sham surgery involved exposure of the sciatic nerve but no ligation and transection. Muscle and skin layers were closed, and animals were returned to their cages and litters. C-fiber stimulation was performed under isoflurane anesthesia as previously described in rats (Hathway et al., 2009). Trains of electrical stimuli were applied through silver wire electrodes placed on the exposed sciatic nerve, for $5 \mathrm{~min}$ at $500 \mu \mathrm{s}, 6 \mathrm{~mA}, 10 \mathrm{~Hz}$ to recruit C-fiber afferents. Sham controls underwent surgery and electrode placement but not electrical stimulation. Mechanical sensitivity was tested 3 and $24 \mathrm{~h}$ post-C-fiber stimulation followed by extraction of dorsal horn tissue.

Sensory behavioral testing. In male rats, sensory reflex withdrawal thresholds of the hindpaw to mechanical, thermal radiant heat stimulation, acetone and ethylchloride application were measured on the ipsilateral and contralateral paw, together with dynamic weight bearing, $1 \mathrm{~d}$ before surgery (baseline) and every $7 \mathrm{~d}$ after surgery, not extending beyond $35 \mathrm{~d}$ postsurgery. In male mice, only mechanical thresholds were tested. For all tests, stimuli were applied to the lateral plantar surface of the hindpaw in the sural nerve innervated region. Mechanical thresholds were determined using 50\% paw withdrawal to von Frey hairs (vFh) using the up-down method (Chaplan et al., 1994). Thermal withdrawal latency was determined as the mean latency to withdraw from a beam of radiant heat (Hargreaves et al., 1988), applied twice at an interval of 5 min. Cold pain behavior was assessed as the mean behavioral score, graded according to duration of foot withdrawal, to an acetone drop or an ethyl chloride spray to the lateral plantar surface of the hindpaw applied twice at an interval of $5 \mathrm{~min}$, as described previously (Flatters and Bennett, 2004). Hindlimb weight bearing was measured using an incapacitance meter (Churchill Electronic Services), which measures the weight supported by each hindlimb independently; the mean of three readings from each paw were taken and results are presented as the percentage of weight bearing on the contralateral paw.

Electrophysiology. Electrophysiology was performed in male rats, because they are more robust than mice. Rats were anesthetized with isoflurane (1.8\% in medical oxygen, Univentor unit 400, Royem Scientific) and heart rate and body temperature maintained at physiological levels and the lumbar dorsal horn exposed for recording. Extracellular recordings of wide dynamic range neurons in the deep dorsal horn were made using a $10 \mu \mathrm{m}$ tipped glass-coated tungsten microelectrodes (Ainsworks) using standard recording techniques (NeuroLog). Filtered spikes were digitised (4SP, AD Instruments) and analyzed using Chart 7 software (ADI Instruments). Cells were isolated with cutaneous receptive fields in the "spared" sural area of the rat hindpaw in SNI and sham animals. Spontaneous activity and activity evoked by dynamic tactile stimulation (applied with a no. 3 paintbrush), noxious pinch (applied with calibrated forceps) and innocuous cold (acetone drops) of the cutaneous receptive field were recorded. The number of spikes in a 3 min window following each stimulus was counted.

Intrathecal administration. Intrathecal injections were performed in male mice under brief isoflurane anesthesia $(2.7 \%)$ by spinal cord puncture with a $1 \mathrm{ml}$ insulin syringe between the L5 and L6 level to the CSF (3.5 $\mu \mathrm{l})$. Recombinant rat TNF- $\alpha$ (R\&D Systems, no. 510-RT) or vehicle control was reconstituted at $(10 \mu \mathrm{g} / \mathrm{ml}, \mathrm{pH} 7)$ in sterile PBS containing $0.1 \%$ bovine serum albumin and intrathecally administered $(20 \mathrm{ng}) 7 \mathrm{~d}$ after SNI or sham surgery (Zhang et al., 2011). Mechanical sensitivity was assessed 30 and $180 \mathrm{~min}$ following injection and $1 \mathrm{~d}$ later. Rat IL-10 monoclonal antibody (R\&D Systems, no. JES052A5) or isotype control antibody (R\&D Systems, no. MAB005) were reconstituted $(0.5 \mathrm{mg} / \mathrm{ml})$ in sterile PBS and stored at $-20^{\circ} \mathrm{C}$ until use. Intrathecal injections $(10$ $\mu \mathrm{g}$ ) were administered for 3 consecutive days, 7-9 d after SNI or sham surgery, (Lin et al., 2010). Mechanical sensitivity was tested $1 \mathrm{~h}$ after each injection and $1 \mathrm{~d}$ after the final injection. Lipopolysaccharide (LPS)activated microglia or control (PBS nonactivated microglia), were intrathecally injected into mice $7 \mathrm{~d}$ after SNI or sham surgery. Microglia were prepared from cerebral cortices and spinal cords of 2-day-old postnatal mice ( $n=10$; Nakajima et al., 1992) and subsequently incubated with LPS ( $1 \mathrm{mg} / \mathrm{ml}$; Escherichia coli; Sigma-Aldrich) or an equivalent volume of PBS for $3 \mathrm{~h}$ before intrathecal injection. LPS activation of microglial cultures is confirmed using a cathepsin $S$ release assay and pp38 immunocytochemistry (Clark et al., 2010). Mechanical sensitivity was tested every $1 \mathrm{~h}$ for $6 \mathrm{~h}$ postinjection.

Cytokine arrays and quantitative real-time PCR. These were performed in mice only as the best cytokine reagents are available for this species. Mice were transcardially perfused with PBS and ipsilateral and contralateral L4/L5 lumbar dorsal horn segments were isolated and stored at $-80^{\circ} \mathrm{C}$ until required. For cytokine arrays, (R\&D Systems, mouse cytokine array panel A, no. ARY006), samples were defrosted, homogenized, and protein extracted. Ipsilateral and contralateral dorsal horn protein collected from five animals ( $21 \mathrm{~d}$ after P10 SNI) were added together to produce one $400 \mu \mathrm{g}$ protein sample. Each sample was incubated with a separate array precoated with 40 cytokine/chemokine duplicate antibodies and labeled with streptavidin-HRP-conjugated secondary antibody and developed using chemiluminescence. The intensity of the selected dots was analyzed using Image $1.36(\mathrm{NIH})$ software. Duplicates were averaged and the background subtracted to calculate the mean pixel density for each protein. For quantitative real-time RT-PCR (qPCR), total RNA was extracted from defrosted samples using RNeasy Plus Mini kit (Qiagen) and reverse-transcribed using the SuperScript III reverse transcriptase protocol (Invitrogen). Specific primers including the housekeeping control GAPDH, were designed using IDT SciTools RealTime PCR software (Integrated DNA technologies), and purchased from Sigma-Aldrich. Gene-specific mRNA analysis was performed using MiniOpticon Real-Time system or CFX96 Real-Time system (Bio-Rad). Relative quantities of mRNAs were calculated using the comparative $\mathrm{Ct}$ method (Schmittgen and Livak, 2008).

Enzyme-linked immunosorbent assay. The Mouse IL-10 ELISA kits were purchased from BioLegend (Catalog \#431417). The lumbar spinal cord segments were dissected after sham or SNI surgery. Spinal cord tissues were homogenized in a lysis buffer containing protease and phosphatase inhibitors. Protein concentrations were determined by BCA Protein Assay (Pierce). For each reaction in a 96-well plate, $50 \mu \mathrm{g}$ of proteins were used, and ELISA was performed according to the protocol of the manufacturer.

Statistical analyses. All data were checked for normality (ShapiroWilk) before statistical testing. For behavioral data, 50\% mechanical threshold was logarithmically transformed to $\log 2 \mathrm{vFh}$ force, expressed as mean \pm SEM and analyzed using a two-way ANOVA followed by Bonferroni's post hoc analysis, unless otherwise stated. Electrophysiological data were expressed as spikes sec $^{-1}$ and analyzed using the Mann-Whitney test. RT-PCR data were expressed as mean fold-change compared with sham control \pm SEM and analyzed using a two-tailed Student's $t$ 

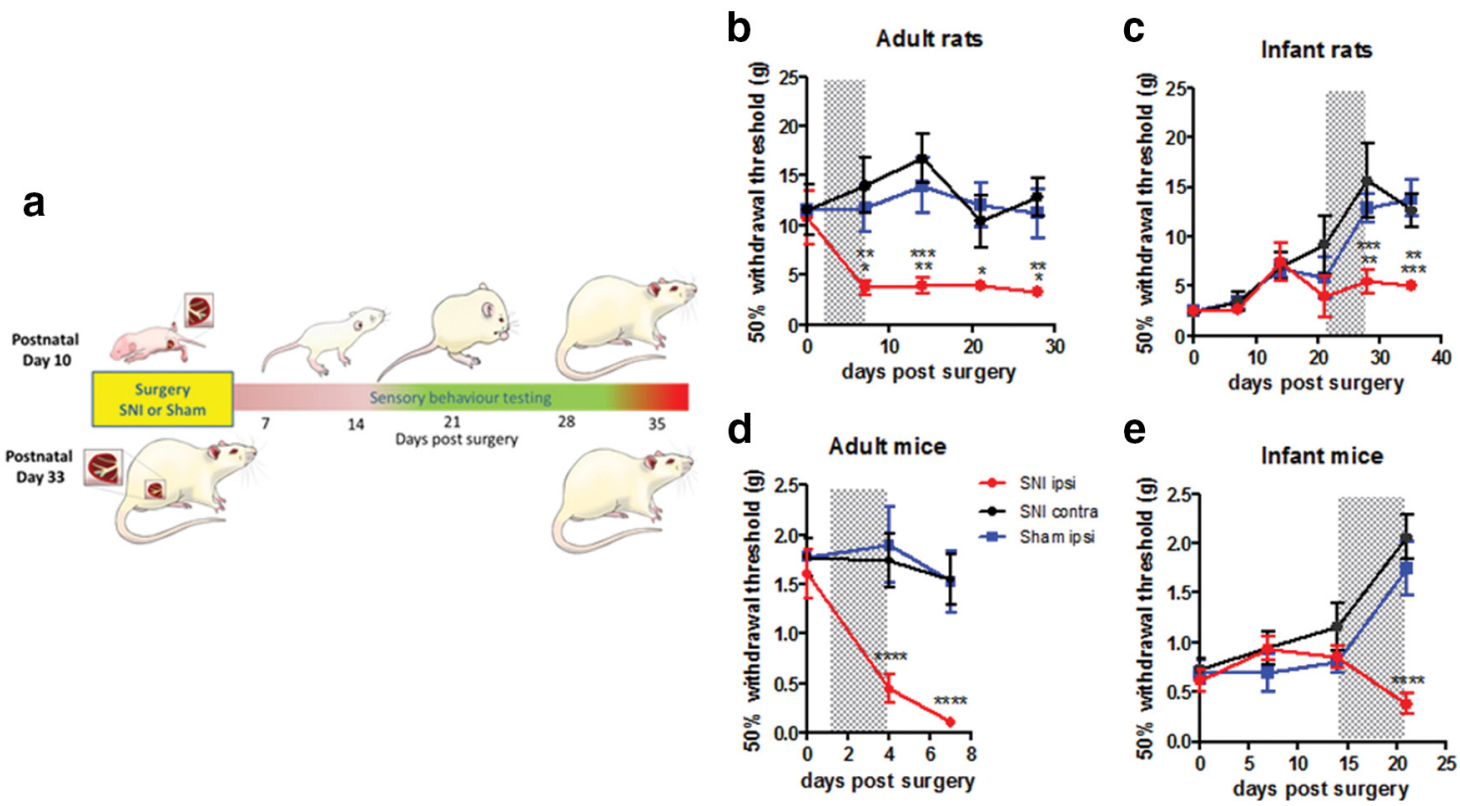

Figure 1. Nerve injury in infant rats and mice produces a delayed-onset adolescent mechanical pain hypersensitivity. $\boldsymbol{a}$, SNI was performed in infant and adult rats and mice, and hindpaw mechanical withdrawal thresholds were tested with vFhs on the ipsilateral paw (SNI ipsi) up to 35 d postsurgery. Results were compared with data from the contralateral paw (SNI contra) and sham surgery (sham ipsi). $\boldsymbol{b}$, SNI causes a rapid decrease in ipsilateral mechanical thresholds in adult rats (two-way ANOVA, $F_{(2,15)}=9.616, p=0.002, \mathrm{SNI}$ surgery: $n=6$, sham surgery: $n=6$, i.e., $n=$ 6 per group) and (d) adult mice within 7 d postsurgery (two-way ANOVA, $F_{(2,12)}=23.28, p<0.0001, n=5$ per group). In contrast, infant SNI has no early effect on mechanical withdrawal thresholds, which increase, as normal, with postnatal age. Thresholds do not fall until $28 \mathrm{~d}$ postsurgery in (c) rats (two-way ANOVA, $F_{(2,19)}=8.487, p=0.0023, n=7$ per group) and $21 \mathrm{~d}$ postsurgery in $(\boldsymbol{e})$ mice (two-way ANOVA, $F_{(2,16)}=8.872, p<0.0026, n=6$ per group). Shaded areas highlight the time period when hypersensitivity develops in each group. Graphs are presented as mean \pm SEM (two-way ANOVA, Bonferroni's post hoc test; ${ }^{*} p<0.05,{ }^{* *} p<0.01,{ }^{* * *} p<0.001,{ }^{* * * *} p<0.0001$ ).

test. The ELISA data were expressed relative to total protein and were analyzed using the Mann-Whitney test. The intrathecal injection data were analyzed using two-way ANOVA and Bonferroni post hoc tests. The criterion for statistical significance was $p<0.05$.

\section{Results}

Nerve injury in infant rats and mice causes no behavioral pain hypersensitivity until adolescence

Spared nerve injury (SNI) in adult rats causes a well established, significant, and persistent mechanical hypersensitivity on the ipsilateral hindpaw within $7 \mathrm{~d}$ postsurgery, which is maintained for at least 3 weeks (Decosterd and Woolf, 2000; Fig. 1a,b). In contrast, the same SNI surgery in infant (P10) rats has no effect on the ipsilateral hindpaw threshold for the first 3 weeks after surgery (Howard et al., 2005; Fig. 1a,c). Mechanical thresholds normally increase with postnatal age and continued to do so even after SNI surgery. Only at $28 \mathrm{~d}$ after SNI, when infant rats are aged P38, do mechanical thresholds in the ipsilateral paw fall significantly below controls (Vega-Avelaira et al., 2012). This mechanical hypersensitivity is maintained until the end of the experiment ( 35 d, 5 weeks postsurgery; Fig. 1a,c).

The same delayed mechanical hypersensitivity occurs in young nerve injured mice. Thus, while SNI in adult mice results in significant mechanical hypersensitivity on the ipsilateral hindpaw recorded 4 and 8 d post-SNI (Fig. 1d; Shields et al., 2003; Bourquin et al., 2006), the same SNI surgery performed in P10 mice had no effect at these time points and only at $21 \mathrm{~d}$ postsurgery, when the young mice were $>4$ weeks old (P31) did mechanical thresholds in the ipsilateral paw decrease (Fig. 1e).

The delayed-onset post-nerve injury hypersensitivity caused by infant SNI was not restricted to mechanical tests. Figure 2 shows that other tests of hindpaw pain sensitivity, namely weight bearing and cold sensitivity to application of acetone and ethylchloride, displayed the same pattern of delayed adolescent onset hypersensitivity. Whereas adult SNI rats develop cool and cold hypersensitivity and reduced ipsilateral weight bearing within $7 \mathrm{~d}$ of surgery (Fig. $2 a-c$ ), infant rats did not display significantly different thresholds in these tests until $21-28 \mathrm{~d}$ post-SNI surgery (Fig. $2 e-g$ ). Hindpaw heat sensitivity was unaffected in both groups compared with controls (Fig. $2 d, h$ ), confirming the absence of any generalized loss of spinal cord function in these animals. Furthermore, Fluoro-Jade C staining for degenerating cells revealed no neuronal degeneration in infant SNI or sham animals, $7 \mathrm{~d}$ postsurgery (data not shown).

These results show that nerve injury in both infant mice and infant rats causes no neuropathic pain behavior until adolescence, using a range of tests of mechanical and cold allodynia.

\section{Infant nerve injury has no effect upon dorsal horn neuronal excitability until adolescence}

To test whether the delayed-onset behavioral hypersensitivity following infant SNI arose from changes in the sensory circuits, we performed "in vivo" dorsal horn cell recordings in isoflurane anesthetized rats at various times post-infant and adult nerve injury. Wide dynamic range (WDR) neurons, with cutaneous receptive fields in the lateral hindpaw region (innervated by the spared sural nerve) were isolated in the deep dorsal horn. Spontaneous activity and activity evoked by dynamic tactile stimulation, noxious pinch, and innocuous cold (acetone) of the cutaneous receptive field were recorded. Figure 3 shows that, $7 \mathrm{~d}$ post-infant SNI surgery mean dorsal horn WDR neuron activity is not significantly different from sham controls, consistent with the absence of pain behavior at this time. However, $28 \mathrm{~d}$ postinfant SNI surgery, when behavioral hypersensitivity has developed, both spontaneous activity and activity evoked by dynamic tactile (brush) and acetone application to the WDR receptive field were significantly greater than in sham controls (Fig. $3 a-c$ ). 
Weight bearing

a
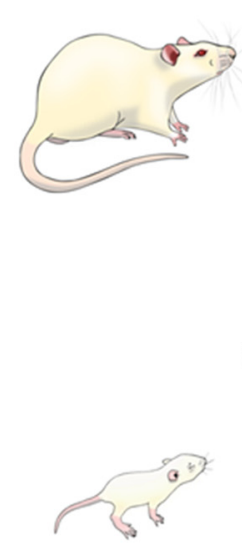

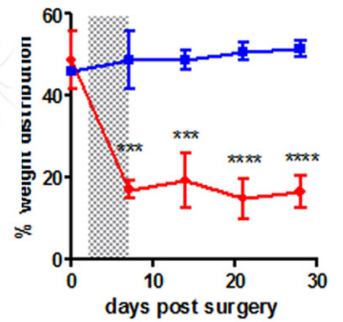

e

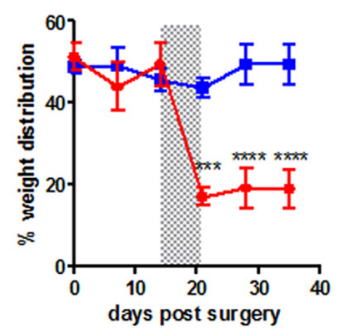

Acetone

b

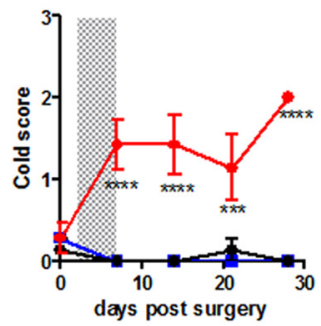

f

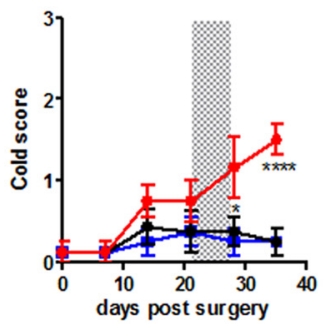

Ethyl chloride

c

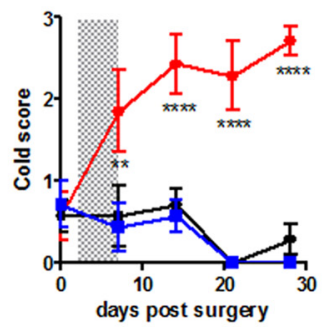

g

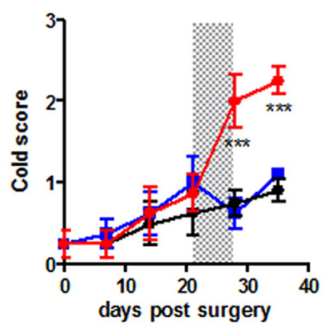

Heat

d

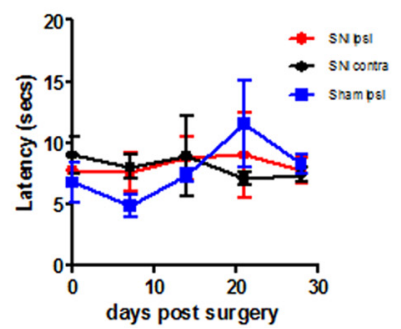

h

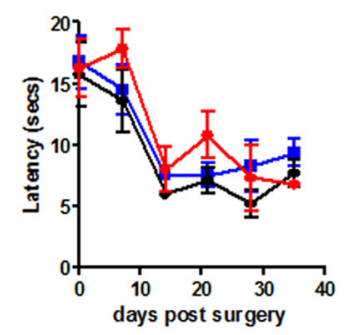

Figure 2. Infant nerve injury causes delayed-onset adolescent weight bearing and cold pain hypersensitivity. Top, Following SNI adult rats develop a rapid decrease in ipsilateral ( $\boldsymbol{a}$ ) weight bearing (SNI surgery: $n=4$, sham surgery: $n=4$, i.e., $n=4$ per group), (b) increase in innocuous cool (acetone, $n=7$ per group), and (c) noxious cold scores (ethyl chloride, $n=8$ per group) $7 \mathrm{~d}$ after surgery, whereas ( $\boldsymbol{d})$ heat sensitivity is not affected ( $n=3$ per group). Bottom, Infant rats display a delayed response to SNI. Significant reductions in ipsilateral (e) weight bearing ( $n=6$ per group), and increases in $(\boldsymbol{f})$ innocuous cool ( $n=8$ per group) and $(\boldsymbol{g})$ noxious cold ( $n=8$ per group) scores develop $2-3$ weeks after infant SNI. $\boldsymbol{h}$, Thermal thresholds ( $n=4$ per group) are reduced over postnatal development but there are no differences between ipsilateral SNI and control paws. Shaded areas highlight the time period when hypersensitivity develops in each group. Graphs are presented as mean \pm SEM (two-way ANOVA, adult rats: weight bearing: $F_{(1,6)}=80.37, p=0.0001, n=4$ per group; acetone $F_{(2,18)}=46.83, p<0.0001, n=7$ per group; ethyl chloride: $F_{(2,18)}$ $=75.29, p<0.0001, n=7$ per group. Infant rats: weight bearing: $F_{(1,10)}=28.13, p=0.0003, n=6$ per group; acetone $F_{(2,21)}=7.65, p=0.0033, n=8$ per group; ethyl chloride $F_{(2,21)}=$ $8.719, p=0.0018, n=8$ per group. Bonferroni's post hoc analysis; $\left.{ }^{*} p=0.05,{ }^{* *} p=0.01,{ }^{* * *} p<0.001 ;{ }^{* * *} p=0.0001\right)$.

Adult WDR cells, on the other hand, developed increased spontaneous activity and acetone evoked activity within $7 \mathrm{~d}$ post-SNI surgery, in agreement with previous studies (Laird and Bennett, 1993; Kohno et al., 2003). There were no significant differences in pinch-evoked activity at any time tested following nerve injury in adults or infants.

These results show that there are no changes in dorsal horn excitability immediately post-infant nerve injury but that neuronal excitability does increase at adolescence, coinciding with pain behavior. This suggests that the mechanism underlying delayedonset pain hypersensitivity following infant SNI surgery lies, at least in part, in the dorsal horn sensory circuits of nerve-injured infants.

Infant nerve injury results in a delayed-onset proinflammatory response in the dorsal horn

Because neuropathic pain in adults is associated with a proinflammatory neuroimmune response in the dorsal horn (Gao and Ji, 2010; Taves et al., 2013), we asked whether the pattern of expression of dorsal horn proinflammatory cytokines and chemokines following infant nerve injury coincides with the pattern of delayed-onset pain behavior. To test this, we performed a screening array of 40 different cytokines and chemokines in ipsilateral and contralateral dorsal horn tissue extracted from mice $21 \mathrm{~d}$ following infant SNI, at the time of onset of pain hypersensitivity. Figure $4 a$ shows that at this time the expression levels of several proinflammatory factors were markedly increased in ipsilateral dorsal horn tissue compared with contralateral dorsal horn, including IL- $1 \alpha$ (7.0-fold), IFN- $\gamma(4.7-$ fold), MIP- $1 \beta$ (13.01-fold), TNF- $\alpha$ (4.5-fold), and KC/ CXCL1 (3.7-fold).
Following this initial screen, we used qPCR to compare the immune profile in the ipsilateral dorsal horn of mice at $7 \mathrm{~d}$ after infant (P10) nerve injury, when there was no pain behavior, and at $21 \mathrm{~d}$, when pain behavior is observed. Expression levels were compared with age matched sham controls. Adult tissue, which exhibits robust rapid increases in dorsal horn glia and proinflammatory mediators following SNI (Coull et al., 2005; Moss et al., 2007; Xu et al., 2013) was used as a positive control.

Figure $4 c-f$ shows that there was no significant difference in the expression of proinflammatory immune markers in the ipsilateral dorsal horn spinal cord compared with sham surgery in mice $7 \mathrm{~d}$ following infant SNI. However, at adolescence, when the mice developed mechanical hypersensitivity, a proinflammatory expression profile develops which is remarkably similar to that seen following adult SNI. This included increases in the microglial activation marker Iba-1 (Fig. 3c), brain-derived neurotrophic factor (BDNF; Fig. $3 d$ ) and tumor necrosis factor $\alpha$ (TNF- $\alpha$; Fig. $3 e$ ) but not the astroglial activation marker glial fibrillary acidic protein (GFAP; Fig. $3 f$ ), which is upregulated following adult nerve injury.

Thus, whereas there is no dorsal horn proinflammatory response in the first weeks after infant nerve injury, proinflammatory cytokine levels rise when mice reach adolescence, coinciding with the onset of behavioral pain hypersensitivity.

\section{Infant nerve injury causes an initial anti-inflammatory response in the dorsal horn}

Given the distinct role of proinflammatory and anti-inflammatory cytokines in pain regulation, we next asked whether the pattern of anti-inflammatory cytokine expression following nerve injury differed in infant and adult mice. Figure $5(a-c)$ shows that qPCR 

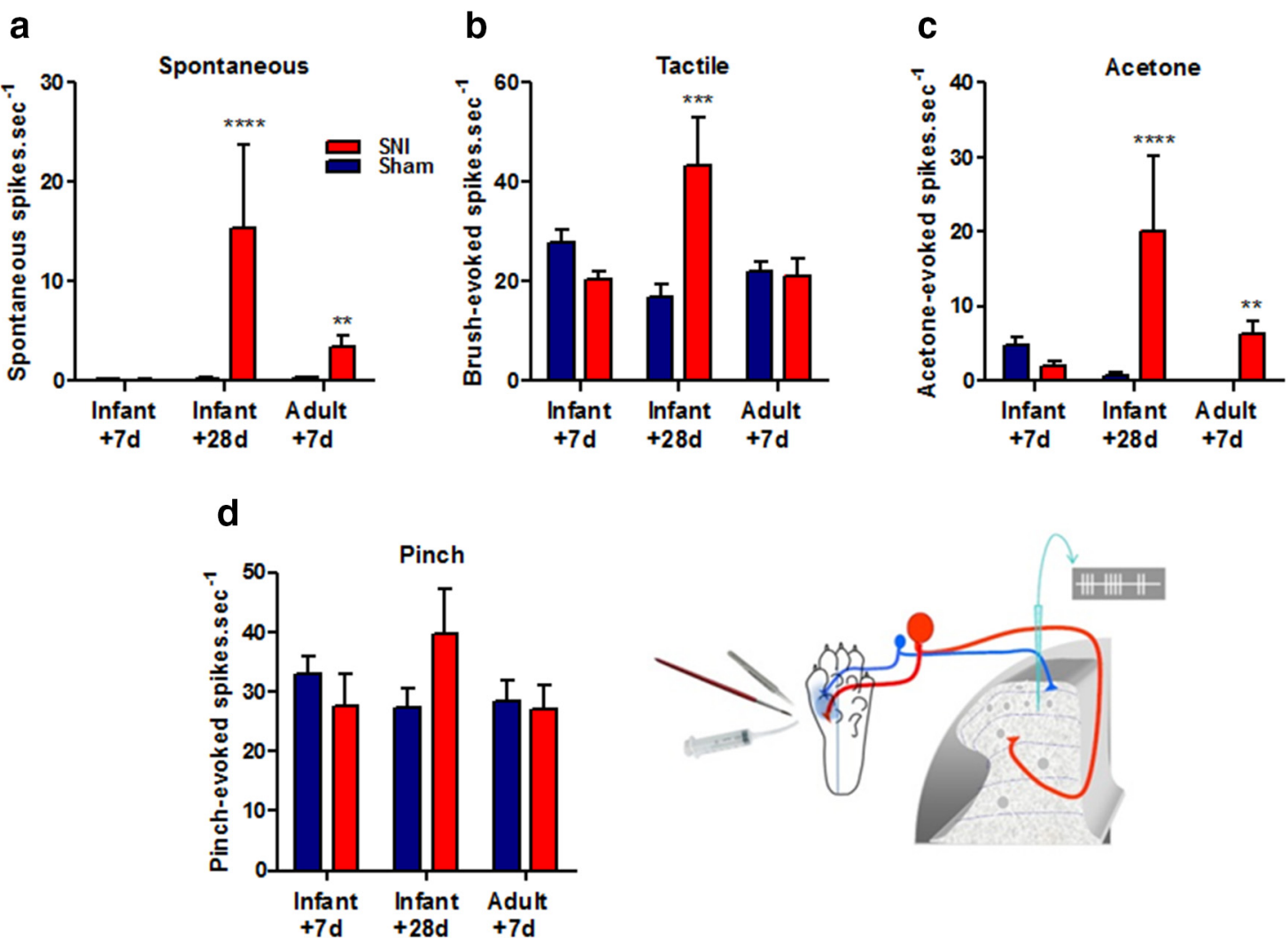

Figure 3. Infant nerve injury leads to a delayed increase in the activity of deep dorsal horn neurons at adolescence. Activity of wide dynamic range neurons in the rat dorsal horn were recorded in response to pinch, tactile brush, and acetone applied to the sural nerve territory of the lateral plantar paw, as illustrated. Spontaneous activity in the absence of stimulation was also recorded. The graphs show that $(\boldsymbol{a})$ in rats $28 \mathrm{~d}$ after infant $\mathrm{SNI}$ and $7 \mathrm{~d}$ after adult $S \mathrm{NI}$, spontaneous activity of dorsal horn neurons increases compared with sham controls (Infant $+28 \mathrm{~d}$ : Sham:0.27 \pm 0.11 spikes $\cdot \mathrm{sec}^{-1}, n=10$ neurons; SNI: $15 \pm 8.5, n=10, p<0.0001$; Adult $+7 \mathrm{~d}$ : Sham $0.31 \pm 0.14 n=19 ; \mathrm{SNI} 3.5 \pm 1.0$ spikes $\left.^{\circ} \mathrm{sec}^{-1}, n=16, p=0.0049\right)$. $\boldsymbol{b}$, There was also a significant increase in dynamic tactile (brush) evoked activity but only in rats $28 \mathrm{~d}$ after infant nerve injury (Infant $+28 \mathrm{~d}$ : Sham:17 $\pm 2.7, n=15 ; \mathrm{SNl}: 43 \pm 9.6, n=10, p=0.0009$ ). c, Acetone-evoked activity increases relative to sham controls in both infants $28 \mathrm{~d}$ after SNI and adults $7 \mathrm{~d}$ after SNI (Infant $+28 \mathrm{~d}$ : Sham:0.70 $\pm 0.35, n=11 ;$;NI: $20 \pm 10, n=9, p<0.0001$; Adult $+7 \mathrm{~d}$ : Sham $0.08 \pm$ $0.05 n=9 ;$ SNI $6.3 \pm 1.8, n=16, p=0.0097)$. $\boldsymbol{d}$, There were no significant differences in pinch evoked activity at any age following SNI ( $n=15-20$ neurons per group). All data expressed as mean \pm SEM neurons recorded from 3 to 4 animals per group and tested for significance using the Mann-Whitney test $\left({ }^{* *} p<0.01,{ }^{* * *} p<0.001,{ }^{* * * *} p<0.0001\right)$.

analysis of ipsilateral dorsal horn tissue $7 \mathrm{~d}$ after infant (P10) SNI showed significant upregulation of mRNA expression of the antiinflammatory cytokines, IL-10, IL-4, and GATA3, a key transcription factor involved in the production of anti-inflammatory cytokines (Ouyang et al., 1998; Ferber et al., 1999). Furthermore, SNI cause a significant, $40 \%$, increase in IL-10 protein levels in the ipsilateral dorsal horn, at $7 \mathrm{~d}$ post-nerve injury, compared with contralateral and sham dorsal horn (Fig. $5 d$ ). However, $21 \mathrm{~d}$ after infant P10 SNI, when the mice had reached adolescence and developed mechanical hypersensitivity, the anti-inflammatory response was no longer evident. At this later time point, there was no difference in the expression of the anti-inflammatory mediators, IL-4 and IL-10, and a significant reduction in GATA3, in the dorsal horn compared with sham controls. In contrast to young animals, adult mice showed no anti-inflammatory response $7 \mathrm{~d}$ post-SNI surgery (Fig. $5 a-c$ ).

These data show that infant nerve injury triggers a robust, early onset anti-inflammatory response in the dorsal horn which precedes the late onset adolescent proinflammatory response.

\section{Dorsal horn anti-inflammatory cytokines are upregulated by} direct C-fiber stimulation in infants but not adults

To test whether noxious C-fiber stimulation alone, in the absence of nerve damage, is able to activate anti-inflammatory mediators in infant mice, we stimulated the sciatic nerve in P10 and adult mice at C-fiber intensities for $5 \mathrm{~min}$ and measured anti- inflammatory cytokine levels in the dorsal horn. As reported in rats (Hathway et al., 2009) brief C-fiber stimulation resulted in a significant decrease in mechanical hindpaw sensory thresholds, 3 and $24 \mathrm{~h}$ after $\mathrm{C}$-fiber stimulation in adult mice (Fig. $6 a$ ) but not in infant mice (Fig. 6b). Ipsilateral dorsal horn tissue taken from adult and infant mice $24 \mathrm{~h}$ following C-fiber stimulation or sham surgery was analyzed using qPCR. In infant mice, C-fiber stimulation increased the expression of both IL-4 and IL10 compared with sham controls (Fig. 6c). In contrast, no changes in the expression of anti-inflammatory mediators were observed in adults. At both ages, anti-inflammatory interleukin 13 (IL-13) and transforming growth factor beta $(\operatorname{Tgf}-\beta)$ did not vary in expression.

These data show that peripheral C-fiber activity alone is sufficient to stimulate an anti-inflammatory response in the dorsal horn of infant, but not adult mice.

Blockade of dorsal horn anti-inflammatory activity in infant rats unmasks neuropathic pain

To test whether the upregulated anti-inflammatory cytokines in infant SNI mice were actively suppressing neuropathic pain in the weeks following surgery, we blocked IL-10 activity after SNI and sham surgery in infant mice for 3 consecutive days (7-9 d postsurgery). Intrathecal anti-IL-10 $(10 \mu \mathrm{g})$ was administered and mechanical hindpaw thresholds tested $1 \mathrm{~h}$ after each injection. Figure $7 a$ shows that blocking IL-10 activity significantly de- 
a

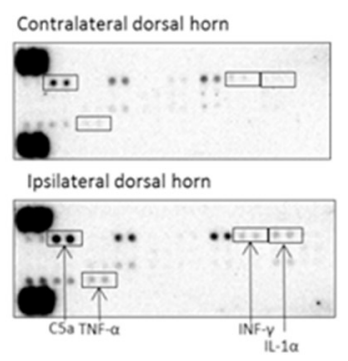

e

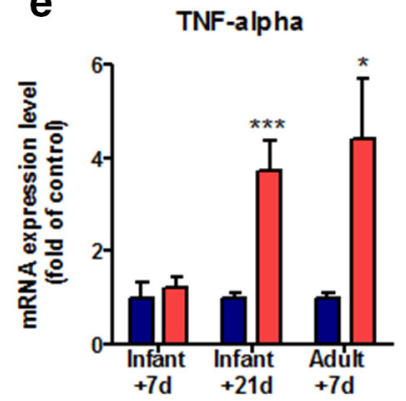

b

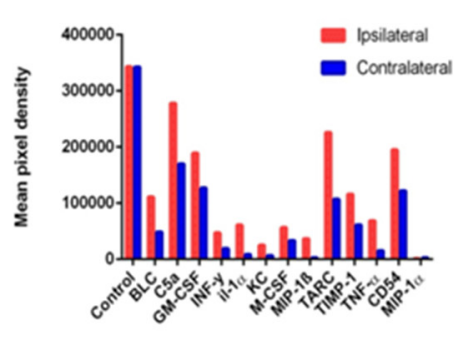

d

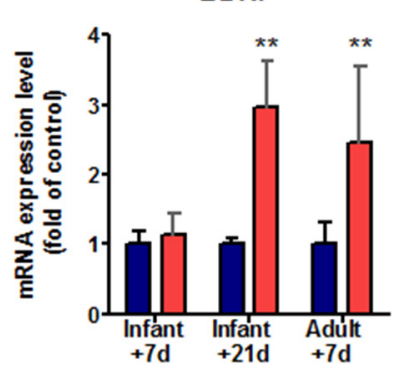

IBA-1

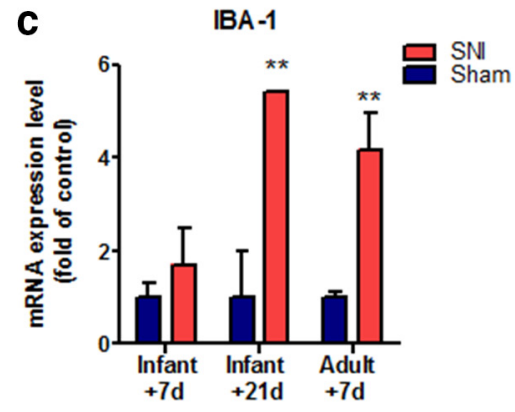

f

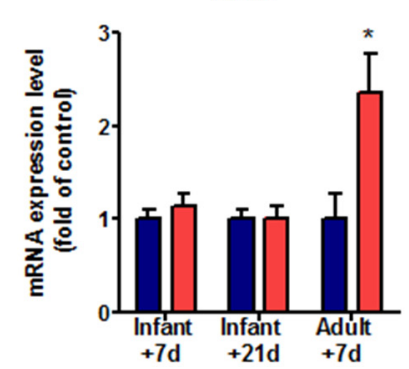

Figure 4. A proinflammatory immune response emerges $21 \mathrm{~d}$ after infant nerve injury. The expression of inflammatory mediators in the ipsilateral dorsal horn spinal cord was compared with contralateral dorsal horn spinal cord tissue extracted from mice $21 \mathrm{~d}$ after infant SNI. $\boldsymbol{a}$, Cytokine array blots incubated (400 $\mu \mathrm{g}$ overnight at 40C) with mouse ipsilateral dorsal horn tissue exhibit higher levels of inflammatory mediator proteins compared with those incubated with contralateral dorsal horn. $\boldsymbol{b}$, Shows the signal (pixel density) of duplicate spots (minus an averaged background), which indicate the increase in the protein levels of many cytokines in the ipsilateral dorsal horn: BLC, CXCL13, C5a, GM-CSF, IFN- $\gamma$, IL-1 $\alpha$, KC, M-CSF, MIP-1 $\beta$, CCL3, TARC, CCL17, TIMP-1, TNF- $\alpha$, CD54, ICAM-1, MIP- $1 \alpha$, and CCL3. Note the control protein levels in the two arrays are comparable (average data from two replicates of one pooled sample from 5 animals). $\boldsymbol{c}-\boldsymbol{f}$, The mRNA expression of inflammatory markers was examined using real-time qPCR in ipsilateral dorsal horn tissue collected from mice $7 \mathrm{~d}$ after infant SNI, $21 \mathrm{~d}$ after infant SNI and $7 \mathrm{~d}$ after adult SNI, and compared with age-matched sham controls. Infant mice do not display any increase in the expression of inflammatory mediators $7 \mathrm{~d}$ after SNI. In contrast, $21 \mathrm{~d}$ after infant SNI there is an increase in (c) Iba-1, (d) BDNF, and (e) TNF- $\alpha$, but not (f) GFAP compared with sham controls. An increase in these markers is also observed in adults $7 \mathrm{~d}$ after SNI in addition to GFAP. Data expressed as fold of sham controls \pm SEM (Student's t test, IBA1: P10 $+21, n=4,{ }^{* *} p=0.004 ;$ P33 $+7, n=6,{ }^{* *} p=0.003 ;$ TNF: P10 $+21, n=8{ }^{* * *} p=0.001 ; \mathrm{P} 33+7, n=5,{ }^{*} p=0.03 ;$ BDNF: P10 + $\left.21, n=8{ }^{* *} p=0.004 ; \mathrm{P} 33+7, n=4,{ }^{* *} p=0.002 ; \mathrm{GFAP}: \mathrm{P} 33+7, n=6,{ }^{*} p=0.02\right)$.

creased the hindpaw mechanical thresholds on the nerve injured side. Three daily injections were administered and the second and third of these resulted in neuropathic pain hypersensitivity in infant SNI but not sham operated mice. Thresholds recovered $24 \mathrm{~h}$ after the last injection. Intrathecal injection of the control antibody (IgG, $10 \mu \mathrm{g}$ ) into infant SNI mice did not induce significant changes in mechanical thresholds. In adults, intrathecal administration of anti-IL-10 after SNI had no significant effect on mechanical thresholds at any time (data not shown).

We next tested whether the dorsal horn anti-inflammatory activity triggered by infant nerve injury could be overcome by direct application or stimulation of proinflammatory cytokines. To examine this we first delivered an intrathecal injection of TNF- $\alpha$ (20 ng) to mice on day 7 after infant SNI or sham surgery and tested mechanical thresholds. TNF- $\alpha$ induced a significant reduction in mechanical thresholds 30 and $180 \mathrm{~min}$ after injection in both SNI and sham-treated rats which recovered $1 \mathrm{~d}$ later (Fig. 7b). Next we tested the effect of intrathecal administration of LPS-activated microglia (1000 cells/10 $\mu$ l), which are known to trigger an innate proinflammatory immune response in adult spinal cord (Harry, 2013). Application of LPS-activated microglia to the spinal cord, $7 \mathrm{~d}$ after infant nerve injury, but not sham surgery, also significantly reduced mechanical thresholds $1 \mathrm{~h}$ after injection for up to $4 \mathrm{~h}$ (Fig. $7 c$ ).

These data demonstrates that blockade of the predominant anti-inflammatory activity in the early post-nerve injury period can unmask infant neuropathic pain and that the balance of anti- inflammatory versus proinflammatory mediators determines pain threshold in nerve-injured infant mice.

\section{Discussion}

The results presented here provide significant new insight into the ontogeny of neuropathic pain. They offer a novel mechanistic explanation for the absence of pain following nerve damage in infants and young children, for the increasing incidence of neuropathic pain with age in the pediatric population and the notable onset of complex neuropathic pain syndromes of unexplained origin in adolescence.

Nerve injury in infants fails to evoke the characteristic rapid onset pain and allodynia or the underlying dorsal horn neuron sensitization that normally follows adult nerve injury (Howard et al., 2005). We show that this failure to cause pain is paralleled by the absence of early proinflammatory response in the dorsal horn of the spinal cord. In adults, the role of the immune system in the development and maintenance of neuropathic pain is well documented and is dominated by a rapid onset proinflammatory response that leads to the sensitization of neurons in the dorsal horn and pain-like hypersensitivity (Coull et al., 2005; Gao and Ji, 2010; Taves et al., 2013). Here we show that in infant mice, SNI failed to increase the expression of either microglia (IBA-1) and astrocyte (GFAP) markers or the expression of proinflammatory mediators TNF $\alpha$, BDNF, or IFN- $\gamma$ in the dorsal horn spinal cord $7 \mathrm{~d}$ postsurgery, despite significant upregulation of these markers in response to SNI in adults. This supports previous reports that 


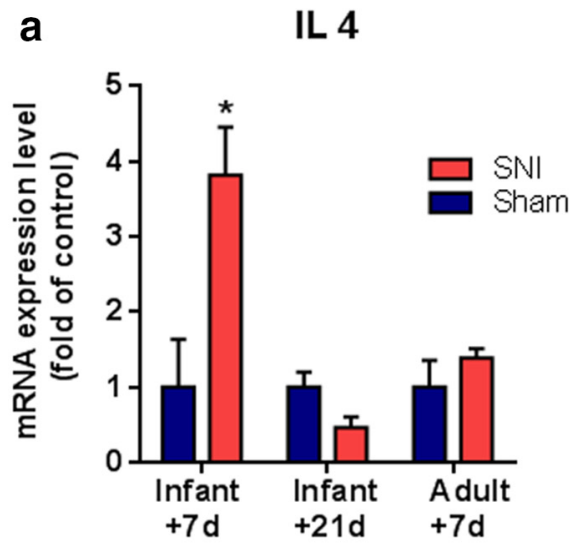

C GATA3

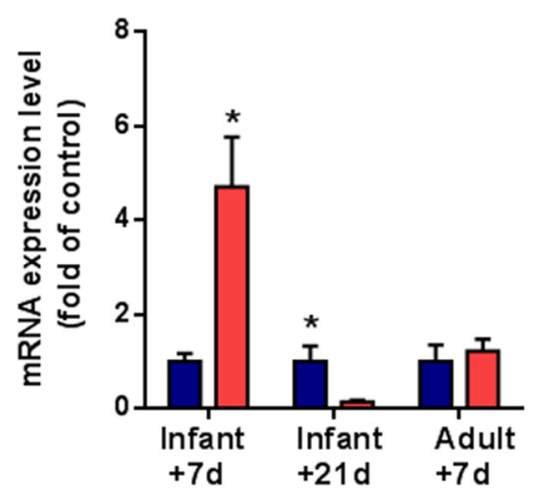

b

IL-10

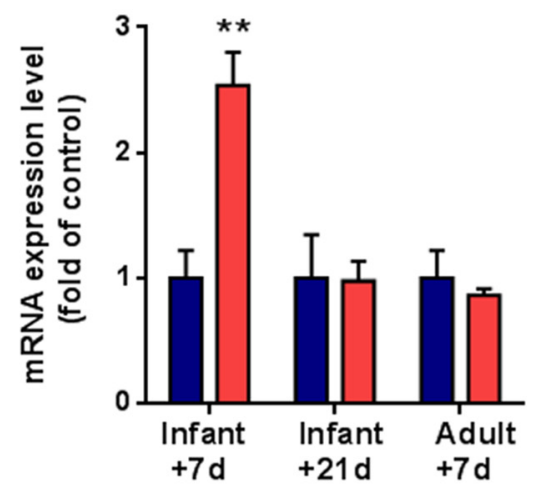

d

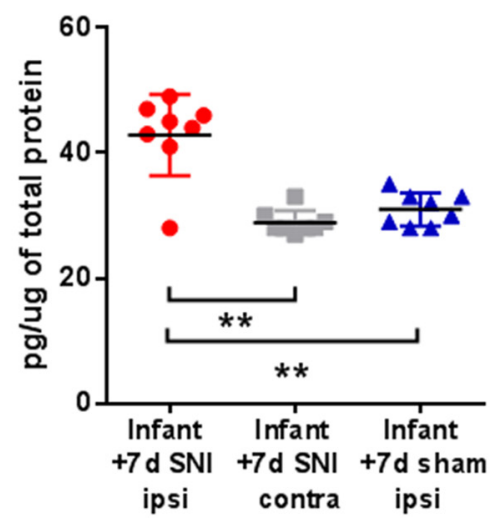

Figure 5. Infant nerve injury causes an acute increase in the expression of anti-inflammatory immune markers. Real time $q P C R$ analysis shows that $7 \mathrm{~d}$ following infant SNI mice display an increase in mRNA expression of anti-inflammatory cytokines (a) IL-4, (b) IL10, and (c) GATA3 in the ipsilateral dorsal horn compared with sham controls. In contrast, $21 \mathrm{~d}$ after infant SNI the expression of IL-10 and IL-4 is comparable to sham controls, whereas GATA3 expression is decreased below the levels of sham controls. In adults, the expression of IL-10, IL-4, and GATA3 in SNI-treated mice remain comparable to sham controls. Data expressed as fold of sham controls \pm SEM (Student's $t$ test, IL4: $\left(\mathrm{P} 10+7 n=4,{ }^{*} p=0.028 ; \mathrm{P} 10+2, n=4 ; \mathrm{P} 33+7, n=6\right), \mathrm{IL} 10:(\mathrm{P} 10+7, n=$ $\left.4 ;{ }^{* *} p=0.004 ; \mathrm{P} 10+21, n=6 ; \mathrm{P} 33+7, n=4\right) ; \mathrm{GATA3}:\left(\mathrm{P} 10+7, n=5,{ }^{*} p=0.03 ; \mathrm{P} 10+21, n=4 ; \mathrm{P} 33+7 n=4\right) \cdot \boldsymbol{d}$ ELISA analysis shows that $7 \mathrm{~d}$ following infant SNI there is a significant increase in IL-10 protein in the ipsilateral mouse dorsal horn compared with the contralateral side and to sham controls. Data expressed relative to total protein in each sample, mean (horizontal lines) \pm SEM (Mann-Whitney test, ${ }^{* *} p=0.003$ SNI ipsi vs contra, $p=0.008$ SNi vs sham, $n=8$ animals per group).

microglial markers, TNF $\alpha$ or IFN- $\gamma$ are not upregulated in the infant rat dorsal horn following SNI (Moss et al., 2007; Costigan et al., 2009).

Instead of a proinflammatory response, SNI in infants induced a striking increase in the expression of anti-inflammatory mediators, characterized by an increase in the expression of the transcription factor GATA3, and the cytokines, IL-10 and IL-4, as well as an increase in IL-10 protein. GATA3 is an important regulator of T-cell development and promotes the differentiation of CD4 T cells into a Th2-cell lineage, and the secretion of antiinflammatory cytokines including IL-4, IL-10, and IL-13, while inhibiting Th1 cell differentiation and IFN- $\gamma$ production (Ouyang et al., 1998; Ferber et al., 1999). IL-4 signaling induces T-cell proliferation and differentiation into a Th2 phenotype, and suppresses macrophage and microglia M1 phenotypes and proinflammatory mediator expression (Stein et al., 1992). IL-10 also acts to inhibit proinflammatory mediator release, as well as reducing the recruitment of immune related glia cells in the spinal cord (Gordon, 2003; Ponomarev et al., 2005; Milligan and Watkins, 2009). Although the origin of the upregulated IL-10, IL-4, and GATA3 following infant nerve injury is not known, these markers are commonly associated with $\mathrm{T}$ cells. However, resident $\mathrm{CD}^{2+} \mathrm{T}$ cells are not increased following infant nerve injury (Costigan et al., 2009) and the source may be microglia (Ponomarev et al., 2005; Milligan and Watkins, 2009), because IL-10 release and IL-10 mRNA expression are increased by LPS activation of microglia derived from infant spinal cords (Werry et al., 2011).

The novel anti-inflammatory response to nerve injury reported here is consistent with the "default" neonatal immune response in neonates being skewed in an anti-inflammatory direction (Adkins, 2000; PrabhuDas et al., 2011; Elahi et al., 2013), and T cells and microglia exhibiting predominantly Th2 and M2 profile, respectively (Scheffel et al., 2012). The predominant anti-inflammatory response during the postnatal period may prevent excessive responses to microbes following the transition from the sterile environment in utero (Maynard et al., 2012) and facilitate microglial "synaptic stripping," removing damaged cells and dysfunctional synapses during development (Kettenmann et al., 2013). In other words, the antiinflammatory response to nerve damage in infants may be the indirect consequence of the requirements for normal postnatal development in the dorsal horn (Beggs et al., 2002; Bremner and Fitzgerald, 2008; Koch et al., 2012).

The dominant anti-inflammatory response following nerve injury does not mean that immature pain circuits are incapable of responding to proinflammatory mediators, such as TNF. Nerve injury sensitizes neonatal lamina I neurons to TNF in vitro (Li and Baccei, 2011), and here we show that intrathecal TNF- and LPS-activated microglia both overcome the anti-inflammatory activity and induce mechanical hypersensitivity in mice $7 \mathrm{~d}$ after infant SNI. LPS is a bacterial endotoxin that activates Toll-like receptor 4 and subsequently MAPK and NF- $\kappa$ B signaling pathways in microglia involved in the release of proinflammatory cytokines TNF $\alpha$ and IL- 6 that also efficiently downregulate IL-10 (Harry, 2013). LPS-activated microglia release TNF at lower concentrations than the single TNF injection administered here (Welser-Alves and Milner, 2013; Berta et al., 2014); these lower levels of TNF sensitized young SNI mice, while leaving sham animals of the same age unaffected. However, despite being able to respond to stressors such as TNF or LPS-activated microglia, infant mice do not normally produce TNF and BDNF following infant nerve injury, due to an anti-inflammatory response.

Especially important here is our finding that blocking IL-10 following infant SNI unmasked pain behavior causing infant mice to develop mechanical hypersensitivity. Thus the release of IL-10 following nerve injury is functionally essential for the absence of mechanical hypersensitivity. Neuropathic pain is there- 
a

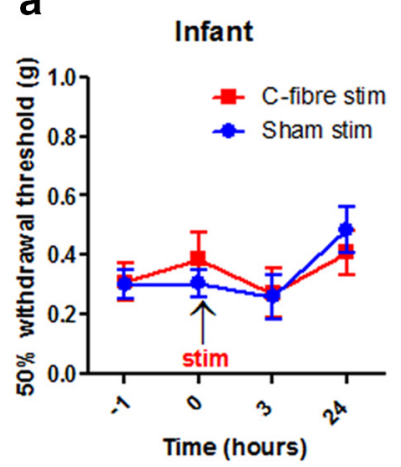

b

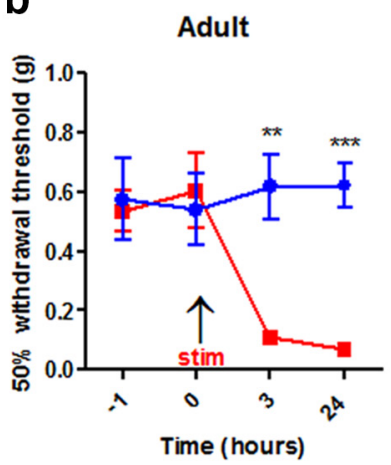

C

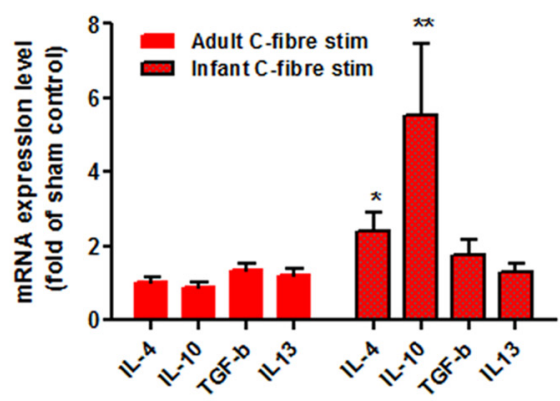

Figure 6. Brief C-fiber nerve stimulation in mice increases expression of anti-inflammatory cytokines in the dorsal horn. $\boldsymbol{a}, \mathrm{C}-$ fiber stimulation ( $6 \mathrm{~mA}, 500 \mu \mathrm{s}$ ) at $10 \mathrm{~Hz}$ for $5 \mathrm{~min}$ of the sciatic nerve in adult mice reduced mechanical thresholds $3 \mathrm{~h}$ after stimulation, and this reduction persisted for at least $24 \mathrm{~h}$ (tw0-way AN0VA, $F_{(1,14)}=13.6 ; p=0.0027$, sham, $n=$ 7, stimulation $n=9$, Bonferroni post hoc analysis, $p=0.003$ at $3 \mathrm{~h}, p=0.001$ at $24 \mathrm{~h}$ ). $\boldsymbol{b}$, The same stimulation protocol in infant mice had no effect upon mechanical thresholds compared with sham animals ( $n=8 /$ treatment group). Data expressed as mean-fold \pm SEM. $c$, In infants $24 \mathrm{~h}$ following C-fiber stimulation real time $q P C R$ analysis reveal an increase in the mRNA expression of IL-10 and IL-4 compared with sham controls, which is not present in adults [IL4, $p=0.0156$ (P33, $n=6 ;$ P10, $n=5) ; I L 10: p=0.046$ (P33, $n=5 ; \mathrm{P} 10, n=$ 5); TGF $\beta, p=0.368$ (P33, $n=4 ; \mathrm{P} 10, n=5) ; I \mathrm{IL} 13: p=0.791$ (P33, $n=6 ; \mathrm{P} 10, n=6)$ ]. Data expressed as fold of sham controls \pm SEM; $n=$ number of animals. Student's $t$ test * $p<$ $0.05,{ }^{* *} p<0.01$.

a

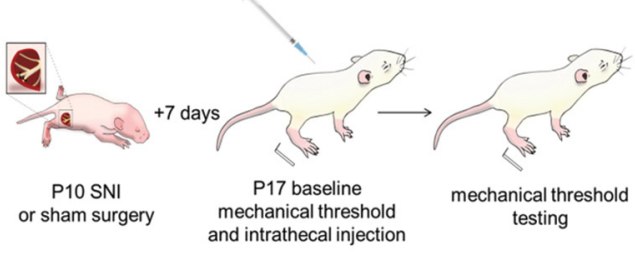

b

TNF $\alpha$

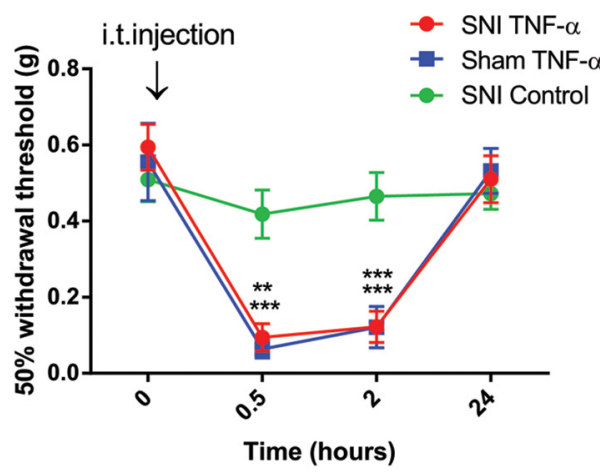

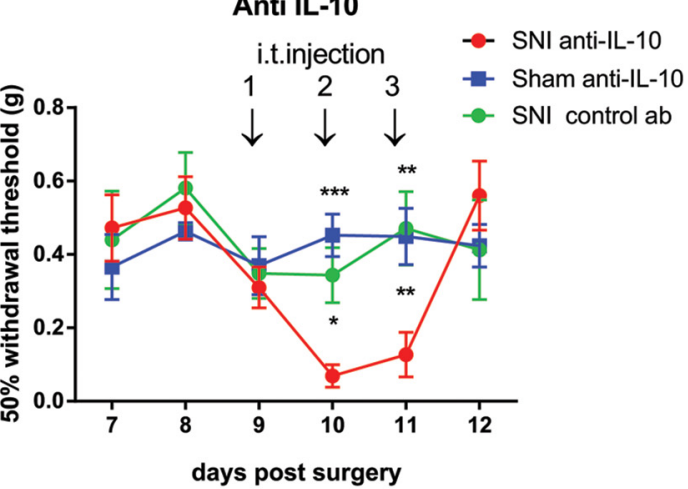

C

Activated microglia

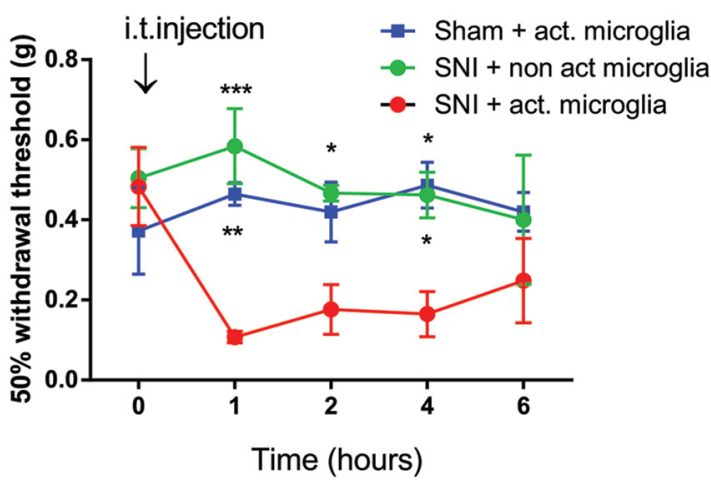

Figure 7. Blocking anti-inflammatory cytokines unmasks hypersensitivity in infants after nerve injury. Illustration shows that infant mice received daily intrathecal injections of anti-IL-10 (10 $\mu \mathrm{g} / 4 \mu$ l or control antibody) $7 \mathrm{~d}$ after infant SNI for $3 \mathrm{~d}$ (days $7-9$ after surgery). $\boldsymbol{a}$, SNI mice treated with anti-IL-10 displayed a decrease in mechanical thresholds $1 \mathrm{~h}$ after the second and third injection, but recovered $1 \mathrm{~d}$ later. SNI mice treated with control antibody or sham mice treated with anti-IL-10 showed no change in mechanical thresholds (two-way ANOVA postinjection, treatment effect $p=0.006 ; F_{(2,15)}=7.379, n=6$ per treatment group; Bonferroni post hoc comparison, post-second injection: ${ }^{*} p=0.02,{ }^{* * *} p=0.001$; post-third injection: ${ }^{* *} p=0.0032$ and 0.006$) . \boldsymbol{b}$, Intrathecal administration of TNF- $\alpha(20 \mathrm{ng})$ to infant mice $7 \mathrm{~d}$ after infant SNI caused a significant reduction in mechanical thresholds in sham and SNI-treated animals 3-180 min after injection, which recovered to baseline after $1 \mathrm{~d}$ (two-way ANOVA, treatment effect: $\left.p=0.009, F_{(2,18)}=6.159\right), n=7$ per treatment group; Bonferroni post hoc comparison $0.5 \mathrm{~h}:{ }^{* *} p=0.0013,{ }^{* * *} p=$ $0.0003 ; 3 \mathrm{~h}:{ }^{* *} p=0.0006$ and $\left.p=0.0004\right)$.c, Infant mice $(n=5)$ received one $4 \mu$ lintrathecal injections of LPS-activated microglia or PBS nonactivated microglia control (1000 cells $\left./ 10 \mu l\right) 7 \mathrm{~d}$ after infant SNI or sham surgery and mechanical thresholds were tested every hour. Only SNI-treated mice but not sham-treated mice displayed a decrease in mechanical thresholds to LPS-activated microglia (two-way ANOVA, treatment effect: $\left.p=0.002, F_{(2,12)}=10.68\right), n=5$ per treatment group; Bonferroni post hoc comparison $1 \mathrm{~h}:{ }^{* * *} p=0.002,{ }^{* *} p=0.007 ; 2 \mathrm{~h}:{ }^{*} p=0.038,4 \mathrm{~h}:{ }^{*} p=$ 0.032 and 0.018 ). Thresholds of control animals show a nonsignificant decrease in baseline, arising presumably from repeated testing of animals treated ( $n=6 /$ treatment group). Graphs show mean \pm SEM. 
fore not absent, but actively suppressed and can be unmasked if the anti-inflammatory response is blocked. Exogenous IL-10 and IL-4 are anti-nociceptive in adult neuropathic models, suppressing proinflammatory cytokines, microglia responses and pain behavior (Milligan et al., 2005a,b; Hao et al., 2006) and our results show that in infants this antinociception naturally dominates following nerve injury.

The infant anti-inflammatory response does not require actual nerve damage; we show here that it can also be evoked by brief stimulation of intact afferent $\mathrm{C}$-fiber nociceptors in infants. The same C-fiber stimulation in adults induces pain hypersensitivity and microglia activation in the spinal cord, that are attenuated by pretreatment with minocycline (Hathway et al., 2009), an inhibitor of proinflammatory polarized microglia (Kobayashi et al., 2013), thus transiently mimicking changes in dorsal horn that underpin chronic pain states (Taves et al., 2013). The fact that C-fiber stimulation in infants stimulates expression of antiinflammatory IL-10 and IL-4, suggests that their release can be directly activated by C-fiber neurotransmitters in the dorsal horn and that the response following infant nerve injury could result from activity in damaged C-fiber afferent terminals. Interestingly, IL-10 release from neonatal spinal cord microglia is potentiated by the excitatory neurotransmitter glutamate (Werry et al., 2011).

We show here that as the nerve injured infants grow up, the anti-inflammatory response changes to a proinflammatory response; levels of the anti-inflammatory mediators IL-4 and IL-10 return to control levels and GATA3 falls transiently below control levels, whereas expression of proinflammatory markers, IBA1, BDNF, and TNF $\alpha$ increase. Notably, the switch to a proinflammatory response coincides with a delayed onset of mechanical hypersensitivity and a significant increase in spontaneous, tactile and acetone-evoked activity in dorsal horn neurons, similar to that seen following adult nerve injury (Laird and Bennett, 1993). Because the levels of GFAP do not increase at this time, astrocyte activation is unlikely to drive delayed-onset hypersensitivity. The timing is entirely consistent with the reported postnatal change in TLR inducible cytokine and chemokine release from microglia, which is at its lowest at postnatal day 21 but rises considerably toward adolescence (Scheffel et al., 2012). Furthermore, the delayed-onset hypersensitivity coincides with an increase in IBA-1 immunofluorescence in the ipsilateral dorsal horn (VegaAvelaira et al., 2012). Thus, despite the fact that the nerve injury was performed in infancy, pain behavior emerges at adolescence, at least in part as a result of a change in neuroimmune activity.

These results have considerable relevance to the understanding of pediatric neuropathic pain. Adult nerve injury evokes neuropathic pain characterized by spontaneous pain, tactile and cold allodynia (pain caused by previously innocuous stimuli) and pinprick hyperalgesia (heightened sensitivity to a noxious stimulus), and these features form the basis of the SNI model in rats and mice (Pertin et al., 2012). In contrast, nerve injury in human infants and young children does not cause neuropathic pain (Anand and Birch, 2002), the incidence of pain following nerve injury increasing with age in pediatric patients (Atherton et al., 2008), and this too is a feature of infant rat and mouse nerve injury models (Howard et al., 2005; Costigan et al., 2009). The discovery that delayed-onset pain hypersensitivity emerges at adolescence in animal models is consistent with the observation that infant phantom limb pain does not appear for many years after the original loss of limbs during infancy, in some cases up to 3-15 years later (Melzack et al., 1997). These data may also ex- plain the peak onset of complex pain syndromes, such as complex regional pain syndrome, in adolescent patients (Walco et al., 2010). An injury sustained in early life may have consequences that are initially suppressed by an anti-inflammatory immune response and the shift in the balance of anti-inflammatory to proinflammatory activity at adolescence may reveal latent neuropathic pain hypersensitivity. Tipping the balance in favor of the potentially neuroprotective anti-inflammatory processes may be an especially useful therapeutic approach for such chronic pain patients.

\section{References}

Adkins B (2000) Development of neonatal Th1/Th2 function. Int Rev Immunol 19:157-171. CrossRef Medline

Anand P, Birch R (2002) Restoration of sensory function and lack of longterm chronic pain syndromes after brachial plexus injury in human neonates. Brain 125:113-122. CrossRef Medline

Atherton DD, Taherzadeh O, Elliot D, Anand P (2008) Age-dependent development of chronic neuropathic pain, allodynia and sensory recovery after upper limb nerve injury in children. J Hand Surg Eur Vol 33:186191. CrossRef Medline

Beggs S, Torsney C, Drew LJ, Fitzgerald M (2002) The postnatal reorganization of primary afferent input and dorsal horn cell receptive fields in the rat spinal cord is an activity-dependent process. Eur J Neurosci 16:12491258. CrossRef Medline

Berta T, Park CK, Xu ZZ, Xie RG, Liu T, Lü N, Liu YC, Ji RR (2014) Extracellular caspase- 6 drives murine inflammatory pain via microglial TNF- $\alpha$ secretion. J Clin Invest 124:1173-1186. CrossRef Medline

Bourquin AF, Süveges M, Pertin M, Gilliard N, Sardy S, Davison AC, Spahn DR, Decosterd I (2006) Assessment and analysis of mechanical allodynia-like behavior induced by spared nerve injury (SNI) in the mouse. Pain 122:14.e1-14. CrossRef Medline

Bremner LR, Fitzgerald M (2008) Postnatal tuning of cutaneous inhibitory receptive fields in the rat. J Physiol 586:1529-1537. CrossRef Medline

Chaplan SR, Bach FW, Pogrel JW, Chung JM, Yaksh TL (1994) Quantitative assessment of tactile allodynia in the rat paw. J Neurosci Methods 53:55-63. CrossRef Medline

Clark AK, Wodarski R, Guida F, Sasso O, Malcangio M (2010) Cathepsin S release from primary cultured microglia is regulated by the P2X7 receptor. Glia 58:1710-1726. CrossRef Medline

Costigan M, Moss A, Latremoliere A, Johnston C, Verma-Gandhu M, Herbert TA, Barrett L, Brenner GJ, Vardeh D, Woolf CJ, Fitzgerald M (2009) T-cell infiltration and signaling in the adult dorsal spinal cord is a major contributor to neuropathic pain-like hypersensitivity. J Neurosci 29: 14415-14422. CrossRef Medline

Coull JA, Beggs S, Boudreau D, Boivin D, Tsuda M, Inoue K, Gravel C, Salter MW, De Koninck Y (2005) BDNF from microglia causes the shift in neuronal anion gradient underlying neuropathic pain. Nature 438:10171021. CrossRef Medline

Decosterd I, Woolf CJ (2000) Spared nerve injury: an animal model of persistent peripheral neuropathic pain. Pain 87:149-158. CrossRef Medline

Elahi S, Ertelt JM, Kinder JM, Jiang TT, Zhang X, Xin L, Chaturvedi V, Strong BS, Qualls JE, Steinbrecher KA, Kalfa TA, Shaaban AF, Way SS (2013) Immunosuppressive CD71 + erythroid cells compromise neonatal host defence against infection. Nature 504:158-162. CrossRef Medline

Ferber IA, Lee HJ, Zonin F, Heath V, Mui A, Arai N, O'Garra A (1999) GATA-3 significantly downregulates IFN-gamma production from developing Th1 cells in addition to inducing IL-4 and IL-5 levels. Clin Immunol 91:134-144. CrossRef Medline

Flatters SJ, Bennett GJ (2004) Ethosuximide reverses paclitaxel- and vincristine-induced painful peripheral neuropathy. Pain 109:150-161. CrossRef Medline

Gao YJ, Ji RR (2010) Chemokines, neuronal-glial interactions, and central processing of neuropathic pain. Pharmacol Ther 126:56-68. CrossRef Medline

Gordon S (2003) Alternative activation of macrophages. Nat Rev Immunol 3:23-35. CrossRef Medline

Hao S, Mata M, Glorioso JC, Fink DJ (2006) HSV-mediated expression of interleukin-4 in dorsal root ganglion neurons reduces neuropathic pain. Mol Pain 2:6. CrossRef Medline

Hargreaves K, Dubner R, Brown F, Flores C, Joris J (1988) A new and sen- 
sitive method for measuring thermal nociception in cutaneous hyperalgesia. Pain 32:77-88. CrossRef Medline

Harry GJ (2013) Microglia during development and aging. Pharmacol Ther 139:313-326. CrossRef Medline

Hathway GJ, Vega-Avelaira D, Moss A, Ingram R, Fitzgerald M (2009) Brief, low frequency stimulation of rat peripheral C-fibres evokes prolonged microglial-induced central sensitization in adults but not in neonates. Pain 144:110-118. CrossRef Medline

Howard RF, Walker SM, Mota PM, Fitzgerald M (2005) The ontogeny of neuropathic pain: postnatal onset of mechanical allodynia in rat spared nerve injury (SNI) and chronic constriction injury (CCI) models. Pain 115:382-389. CrossRef Medline

Howard RF, Wiener S, Walker SM (2014) Neuropathic pain in children. Arch Dis Child 99:84-89. CrossRef Medline

Kettenmann H, Kirchhoff F, Verkhratsky A (2013) Microglia: new roles for the synaptic stripper. Neuron 77:10-18. CrossRef Medline

Kobayashi K, Imagama S, Ohgomori T, Hirano K, Uchimura K, Sakamoto K, Hirakawa A, Takeuchi H, Suzumura A, Ishiguro N, Kadomatsu K (2013) Minocycline selectively inhibits M1 polarization of microglia. Cell Death Dis 4:e525. CrossRef Medline

Koch SC, Tochiki KK, Hirschberg S, Fitzgerald M (2012) C-fiber activitydependent maturation of glycinergic inhibition in the spinal dorsal horn of the postnatal rat. Proc Natl Acad Sci U S A 109:12201-12206. CrossRef Medline

Kohno T, Moore KA, Baba H, Woolf CJ (2003) Peripheral nerve injury alters excitatory synaptic transmission in lamina II of the rat dorsal horn. J Physiol 548:131-138. CrossRef Medline

Laird JM, Bennett GJ (1993) An electrophysiological study of dorsal horn neurons in the spinal cord of rats with an experimental peripheral neuropathy. J Neurophysiol 69:2072-2085. Medline

Li J, Baccei ML (2011) Neonatal tissue damage facilitates nociceptive synaptic input to the developing superficial dorsal horn via NGF-dependent mechanisms. Pain 152:1846-1855. CrossRef Medline

Lin SL, Tsai RY, Tai YH, Cherng CH, Wu CT, Yeh CC, Wong CS (2010) Ultra-low dose naloxone upregulates interleukin-10 expression and suppresses neuroinflammation in morphine-tolerant rat spinal cords. Behav Brain Res 207:30-36. CrossRef Medline

Marsh D, Dickenson A, Hatch D, Fitzgerald M (1999) Epidural opioid analgesia in infant rats II: responses to carrageenan and capsaicin. Pain 82:33-38. CrossRef Medline

Maynard CL, Elson CO, Hatton RD, Weaver CT (2012) Reciprocal interactions of the intestinal microbiota and immune system. Nature 489:231241. CrossRef Medline

Melzack R, Israel R, Lacroix R, Schultz G (1997) Phantom limbs in people with congenital limb deficiency or amputation in early childhood. Brain 120:1603-1620. CrossRef Medline

Milligan ED, Watkins LR (2009) Pathological and protective roles of glia in chronic pain. Nat Rev Neurosci 10:23-36. CrossRef Medline

Milligan ED, Langer SJ, Sloane EM, He L, Wieseler-Frank J, O'Connor K, Martin D, Forsayeth JR, Maier SF, Johnson K, Chavez RA, Leinwand LA, Watkins LR (2005a) Controlling pathological pain by adenovirally driven spinal production of the anti-inflammatory cytokine, interleukin10. Eur J Neurosci 21:2136-2148. CrossRef Medline

Milligan ED, Sloane EM, Langer SJ, Cruz PE, Chacur M, Spataro L, WieselerFrank J, Hammack SE, Maier SF, Flotte TR, Forsayeth JR, Leinwand LA, Chavez R, Watkins LR (2005b) Controlling neuropathic pain by adenoassociated virus driven production of the anti-inflammatory cytokine, interleukin-10. Mol Pain 1:9. CrossRef Medline

Moss A, Beggs S, Vega-Avelaira D, Costigan M, Hathway GJ, Salter MW, Fitzgerald M (2007) Spinal microglia and neuropathic pain in young rats. Pain 128:215-224. CrossRef Medline

Nakajima K, Shimojo M, Hamanoue M, Ishiura S, Sugita H, Kohsaka S (1992) Identification of elastase as a secretory protease from cultured rat microglia. J Neurochem 58:1401-1408. Medline
Ouyang W, Ranganath SH, Weindel K, Bhattacharya D, Murphy TL, Sha WC, Murphy KM (1998) Inhibition of Th1 development mediated by GATA-3 through an IL-4-independent mechanism. Immunity 9:745755. CrossRef Medline

Pertin M, Gosselin RD, Decosterd I (2012) The spared nerve injury model of neuropathic pain. Methods Mol Biol 851:205-212. CrossRef Medline

Ponomarev ED, Shriver LP, Maresz K, Dittel BN (2005) Microglial cell activation and proliferation precedes the onset of CNS autoimmunity. J Neurosci Res 81:374-389. CrossRef Medline

PrabhuDas M, Adkins B, Gans H, King C, Levy O, Ramilo O, Siegrist CA (2011) Challenges in infant immunity: implications for responses to infection and vaccines. Nat Immunol 12:189-194. CrossRef Medline

Scheffel J, Regen T, Van Rossum D, Seifert S, Ribes S, Nau R, Parsa R, Harris RA, Boddeke HWGM, Chuang HN, Pukrop T, Wessels JT, Jürgens T, Merkler D, Brück W, Schnaars M, Simons M, Kettenmann H, Hanisch UK (2012) Toll-like receptor activation reveals developmental reorganization and unmasks responder subsets of microglia. Glia 60:1930-1943. CrossRef Medline

Schmittgen TD, Livak KJ (2008) Analyzing real-time PCR data by the comparative $C(T)$ method. Nat Protoc 3:1101-1108. CrossRef Medline

Sethna NF, Meier PM, Zurakowski D, Berde CB (2007) Cutaneous sensory abnormalities in children and adolescents with complex regional pain syndromes. Pain 131:153-161. CrossRef Medline

Shields SD, Eckert WA 3rd, Basbaum AI (2003) Spared nerve injury model of neuropathic pain in the mouse: a behavioral and anatomic analysis. J Pain 4:465-470. CrossRef Medline

Stein M, Keshav S, Harris N, Gordon S (1992) Interleukin 4 potently enhances murine macrophage mannose receptor activity: a marker of alternative immunologic macrophage activation. J Exp Med 176:287-292. CrossRef Medline

Taves S, Berta T, Chen G, Ji RR (2013) Microglia and spinal cord synaptic plasticity in persistent pain. Neural Plast 2013:753656. Medline

Tsuda M, Beggs S, Salter MW, Inoue K (2013) Microglia and intractable chronic pain. Glia 61:55-61. CrossRef Medline

Vega-Avelaira D, Moss A, Fitzgerald M (2007) Age-related changes in the spinal cord microglial and astrocytic response profile to nerve injury. Brain Behav Immun 21:617-623. CrossRef Medline

Vega-Avelaira D, McKelvey R, Hathway G, Fitzgerald M (2012) The emergence of adolescent onset pain hypersensitivity following neonatal nerve injury. Mol Pain 8:30. CrossRef Medline

Walco GA, Dworkin RH, Krane EJ, LeBel AA, Treede RD (2010) Neuropathic pain in children: special considerations. Mayo Clin Proc 85:S33-41. CrossRef Medline

Walker SM, Howard RF, Keay KA, Fitzgerald M (2005) Developmental age influences the effect of epidural dexmedetomidine on inflammatory hyperalgesia in rat pups. Anesthesiology 102:1226-1234. CrossRef Medline

Wall PD, Devor M, Inbal R, Scadding JW, Schonfeld D, Seltzer Z, Tomkiewicz MM (1979) Autotomy following peripheral nerve lesions: experimental anaesthesia dolorosa. Pain 7:103-111. CrossRef Medline

Welser-Alves JV, Milner R (2013) Microglia are the major source of TNF- $\alpha$ and TGF- $\beta 1$ in postnatal glial cultures; regulation by cytokines, lipopolysaccharide, and vitronectin. Neurochem Int 63:47-53. CrossRef Medline

Werry EL, Liu GJ, Lovelace MD, Nagarajah R, Hickie IB, Bennett MR (2011) Lipopolysaccharide-stimulated interleukin-10 release from neonatal spinal cord microglia is potentiated by glutamate. Neuroscience 175:93-103. CrossRef Medline

Xu ZZ, Berta T, Ji RR (2013) Resolvin E1 inhibits neuropathic pain and spinal cord microglial activation following peripheral nerve injury. J Neuroimmune Pharmacol 8:37-41. CrossRef Medline

Zhang L, Berta T, Xu ZZ, Liu T, Park JY, Ji RR (2011) TNF- $\alpha$ contributes to spinal cord synaptic plasticity and inflammatory pain: distinct role of TNF receptor subtypes 1 and 2. Pain 152:419-427. CrossRef Medline 